\title{
Challenging the moral issues of his time: Proud Ngarrindjeri man of the Coorong, Thomas Edwin Trevorrow (1954-2013)
}

\author{
Karen Hughes
}

Late on Thursday afternoon, 18 April 2013, Uncle Tom Trevorrow the Ngarrindjeri elder who worked tirelessly to create a just and equitable future for his community, and in the process brought countless black and white people together over more than a quarter of a century, sat down to continue working in the office of his beloved Camp Coorong, near Meningie, South Australia. He had just completed an interview for an international documentary on endangered languages with Ernie Dingo. Moments later this remarkable statesman suffered a heart attack just two weeks before his 59th birthday. His sudden passing left his family, many friends and the Aboriginal community across Australia, and internationally, bereft and in deep shock. For many it was, and still is, difficult to imagine a world without Tom.

He was a visionary, and an inspirational leader and teacher who dedicated his life to achieving recognition of Aboriginal rights and to improving the relationship between Aboriginal and non-Aboriginal peoples.

His funeral in Meningie on 2 May 2013 attracted over 1,000 mourners. People spilled out of the small Meningie Uniting Church, the adjoining hall and the specially erected marquee; lining the Princes Highway. Both the South Australian Premier and the Leader of the Opposition attended, and one of two eulogies was delivered by the Premier Jay Weatherill. Those outside witnessed a large mass formation of ngori, pelicans -Tom's ngatji (totem) - soar directly over the church, flying in from across Lake Albert, at the moment the service began. Then just as the service finished the pelicans flew back again, some two hours later.

Tom was a quiet and humble man who worked from his home-base on Ngarrindjeri country. His family was paramount in his life and in spite of his considerable abilities and accomplishments he did not seek personal recognition or financial gain. With his loved and loving wife Aunty Ellen Trevorrow, the respected cultural weaver and educator, and his older brother George Trevorrow, he established Camp Coorong in 1985 through the Ngarrindjeri Lands and Progress Association as 'a race relations and cultural education centre'. They were inspired by earlier Aboriginal political initiatives such as the Tent Embassy. ${ }^{1}$

1 See Hemming 1993: 37-40. 
Camp Coorong has a strong educational and community focus and maintains an acclaimed Ngarrindjeri Cultural Heritage Museum. Many thousands of school children, university students, as well as international and local visitors have benefitted from Camp Coorong's hospitality and unique pedagogy. ${ }^{2}$

Through his knowledge, vision, persistence, and exceptional ability to connect with people from any walk of life, Tom achieved numerous ground-breaking results for Ngarrindjeri and other Aboriginal peoples. His work, alongside Elders such as George Trevorrow and Matt Rigney, instituted profound changes across areas of self-governance, cultural heritage management, cross-cultural education and caring for country that will resonate across the decades and centuries to come. Kungan Ngarrindjeri Yunnan (Hear Ngarrindjeri People Speak) Agreements established with state and regional levels of government have fundamentally changed the dynamic of Ngarrindjeri-government interactions and provided innovative models for workable treaties. ${ }^{3}$

Before his death, Tom was working with the South Australian government on the legal implementation of the Letters Patent, 1836, and other founding documents that encoded hitherto ignored rights for Aboriginal people and their descendants to freely occupy their land and waters. ${ }^{4} \mathrm{He}$ saw this as key to resolving the unfinished business that impacted Ngarrindjeri futures. This may prove one of his greatest legacies.

\section{Growing up on-Country in the Meningie Coorong fringe camps}

Tom Trevorrow was born in 1954 in Meningie, on the south-east side of Lake Albert, the son of Thora Trevorrow (nee Lampard) and Joseph Trevorrow. On his mother's side Tom traced his lineage to the esteemed Elder of the southeast 'Queen' Ethel (Ethel Whympie Watson), and on his father's side to the Ngarrindjeri woman Alice Walker and her Cornish-born husband Jim Trevorrow, an example of one of the many successful cross-cultural marriages from the colonial era. Alice and Jim raised a large family of 13 children at their home at Salt Creek. On Alice's death in 1941, a newspaper article titled 'The Good Samaritan' recalled her many acts of kindness towards travellers who found themselves stranded along the Coorong. ${ }^{5}$ Tom also had this way of helping people, and as Steve Hemming said in the second eulogy at Tom's funeral, 'his door was always open'.

During his early years Tom was raised at the One Mile and Three Mile Fringe Camps on Ngarrindjeri country, by his parents and Elders. 'A camp', Tom

2 See MacGill et al 2012.

3 See Ngarrindjeri Lands and Progress Association 2006; Trevorrow and Hemming 2006.

4 See Trevorrow et al 2010; Berg 2010; Reynolds 1996.

5 See Hughes and Trevorrow (in press) 2014. 
recalled, 'was measured in the miles out of town and the closest we could live to Meningie was one mile because Ngarrindjeri were not allowed to live in the town, with the rest of society'.

In those days the government of the day was always trying to get us to live on missions or reservations. But we didn't want to, so we stayed together in camps administered by Ngarrindjeri elders. We couldn't live on our traditional land anymore because it had been taken away from us by the Europeans so they could make money from European farming practices. They came in and they cleared the land and they put fences up and it became private property, so Ngarrindjeri had no other choice but to go and live in camps on unallocated land where there was still some native vegetation left and kangaroos and emus, wombats, swan, duck, geese, fish etc; our traditional food, and good fresh water. ${ }^{6}$

Tom received an outstanding Ngarrindjeri cultural education from the Old People, who taught him Ngarrindjeri culture, stories, history, how to read and look after Country and to live off the land. Educated in the western system to part-way through sixth grade (because of the restrictions of government policy and restrictions placed on the movements of Aboriginal families), he grew to become a powerful speaker, a passionate advocate for justice, and an influential thinker. Tom possessed a deep understanding of Ngarrindjeri history, country, culture and the way all things are connected. His intellectual framework illumined the thinking of many scholars from fields as diverse as anthropology, hydrology, history, archaeology, linguistics, gender studies, law, education and environmental science - among them Diane Bell, Deane Fergie, Steve Hemming, David Paton, Daryle Rigney, Christopher Wilson, Kelly Wiltshire and myself. When grappling with the tangled borders of Ngarrindjeri and settler history for my doctoral research, Tom always steered me gently in the right direction, free of judgement. ${ }^{7}$ As our children grew together our families formed a strong bond of friendship, as happened with so many of us who researched and received hospitality in Ngarrindjeri country.

Premier Weatherill recalled his admiration and respect for Tom whom he 'counted as a friend', noting Tom had taught him much about leadership; how leadership was not about shouting above everyone, but about bringing people with you. 'When Tom spoke', he observed, 'people listened. Tom always talked about challenging moral issues with integrity and clarity. ${ }^{\prime 8}$ Words to Tom were valuable and weighted: never wasted, always to target truth. Tom's words brought people together across improbable divides. His wife Ellen said 'it was the ancestors who gave him his voice'. ${ }^{9}$ He was equally at home speaking at Harvard University as speaking to primary school students or among groups of disengaged youth.

6 Trevorrow in Marsh 2013.

7 See Hughes 2010, 2012.

8 Weatherill 2013.

9 Eulogy written by the Trevorrow family, delivered by Steve Hemming, Meningie Church, 2 May 2013. 
In addition to his other roles Tom was Chairperson of the Ngarrindjeri Heritage Committee, and following the death of his brother George and his Ngarrindjeri brother Matt Rigney, of the Ngarrindjeri Regional Authority. He lent his unflinching support to Ngarrindjeri women Elders in their long and arduous struggle with developers and the state to protect places on Kumarangk (Hindmarsh Island). This fight eventually saw the women vindicated by the 2001 von Doussa Federal Court judgement, and much later in 2010, by an official apology from the South Australian government. ${ }^{10}$ Tom fought hard for the repatriation and cultural reburial of the stolen remains of Ngarrindjeri Old People held in Australian and overseas museums and scientific collections. He made an important contribution to the negotiations for the co-management of the Coorong National Park, and as Ngarrindjeri spokesperson to the Murray Darling Basin Commission his voice was important in formulating the Murray Darling Basin plan. Tom remembered 'the Coorong black with ducks and brimming with fish, the river flowing with clear water': 'the river flowing', he emphasised, 'keeps Ngarrindjeri country alive'.

The devastating impact of the unlawful removal of his younger brother Bruce Trevorrow from their family by the state in 1957 weighed heavily on Tom. He stood by Bruce during his ten year battle for compensation which resulted in a landmark victory: to date Australia's first and only successful stolen generation court-claim. Sadly Bruce died only months later. In his findings Justice Gray contrasted 'Bruce's impaired ability to cope with the problems of life' resulting from his removal, to 'the resilient lives' enjoyed by Tom and the other siblings raised by their parents in the fringe camps and later in towns throughout Ngarrindjeri country. ${ }^{11}$

\section{Unfinished business: The man in black}

Ah, I'd love to wear a rainbow every day, And tell the world that everything's OK,

But I'll try to carry off a little darkness on my back, Till things are brighter, I'm the Man In Black. ${ }^{12}$

In the clear late afternoon just before sunset the sound of Johnny Cash singing Man in Black rang out over the Meningie cemetery while Tom's family, and his friends, placed handfuls of Coorong-sand, tea-tree twigs and gum-leaves into his final resting place.

Tom was buried wearing black, the colour he always dressed in as a mark of respect for the past, for the ancestors, and the unfinished business that needed to be addressed. He left the world having laid solid groundwork for a brighter

10 See Bell 1998, 2008, 2012.

11 For a more detailed account see Bell 2008; Hughes and Trevorrow 2014; Anthony 2010.

12 Cash 1971. 
future. As Steve Hemming said in the family's eulogy, 'Tom can rest comfortably knowing that he has left really important building blocks for the Ngarrindjeri nation in times to come.'

Tom is survived by his wife Ellen, children Thomas, Frank (deceased), Bruce, Tanya, Joe, Luke and Hank, 16 grandchildren and two great-grandchildren. After long days of meetings and negotiations he could always be found sitting on the verandah with Ellen, their children and their grannies (grandchildren) as the sun set over the Coorong. His partnership with Ellen (that began when they were aged 12 and 11), and their large family was at the core of Tom's life and work and his fight for justice.

Aunty Ellen Trevorrow passionately continues Tom's educational, cultural and political work, as well as her own weaving practice, at Camp Coorong assisted by their family. She is about to travel to Europe for a Ngarrindjeri study-tour of French museums, and to visit the Cornish town in England where Tom's grandfather Jim Trevorrow was born, re-connecting with this branch of the Trevorrow family.

\section{References}

Anthony, T 2010, 'Shaky victory for the Stolen Generations', The Drum, ABC, 10 November 2010, <http://www.abc.net.au/unleashed/40912.html>, (accessed 18 August 2012).

Bell, Diane 1998, Ngarrindjeri Wurruwarrin: A World That Was, Is, and Will Be, Spinifex, North Melbourne.

- (ed) 2008, Kungun Ngarrindjeri Miminar Yunnun: Listen to Ngarrindjeri Women Speaking, Spinifex Press, Melbourne.

- 2010, 'Ngarrindjeri women's stories: Kungun and Yunnan', in Women and Indigenous Religions, S Marcos (ed), Greenwood, California: 3-20.

Berg, Shaun (ed) 2010, Coming to Terms, Aboriginal Title in South Australia, Wakefield Press, Adelaide.

Cash, John 1971, Man in Black @ C House of Cash, Inc, recorded 16 February 1971.

Hemming, Steve 1993, ‘Camp Coorong - combining race relations and cultural education', Social Alternatives 12(1): 37-40.

Hemming, Steve and Tom Trevorrow 2005, 'Kungan Ngarrindjeri Yunnan: Archaeology, colonialism and reclaiming the future', in Indigenous Archaeologies: Decolonising Theory and Practice, Claire Smith and H Martin Wobst (eds), Routledge, London: 243-261. 
Hughes, Karen 2010, 'Fluid Waters: cross-cultural exchange in the land of the Ngarrindjeri', Le Simplegadi 8(8): 24-35.

- 2012, 'Microhistories and things that matter', Australian Feminist Studies 27(73): 269-278.

Hughes, Karen and Ellen Trevorrow (in press) 2014, 'It's that reflection: Ngarrindjeri photography as recuperative practice', in Calling the Shots: Aboriginal Photographies, Jane Lydon and Sari Braithwaite (eds), Aboriginal Studies Press, Canberra.

MacGill, B, J Mathews, E Trevorrow, A Abdulla, and D Rankine 2012, 'Ecology, ontology, and pedagogy at Camp Coorong', M/C Journal 15(3), <http:/ / journal.media-culture.org.au/index.php/mcjournal/article/view/499>, (accessed 17 September 2012).

Marsh, Bill 2013, Interview with Tom Trevorrow, 'About Country', One River, 15 May 2013, <http://oneriver.com.au/tag/tom-trevorrow/>, (accessed 16 September 2013).

Ngarrindjeri Lands and Progress Association 2006, Ngarrindjeri Nation YarluwarRuwe Plan: Caring for Ngarrindjeri Sea Country and Culture, Ngarrindjeri Tendi, Ngarrindjeri Heritage Committee, Ngarrindjeri Native Title Committee, Ngarrindjeri Lands and Progress Association, Camp Coorong, Meningie.

Reynolds, Henry 1996, Aboriginal Sovereignty, Allen \& Unwin, Crows Nest.

Trevorrow, George, Tom Trevorrow and Matthew Rigney 2010, 'Preface', in Coming to Terms, Aboriginal Title in South Australia, Shaun Berg (ed), Wakefield Press, Adelaide.

Trevorrow, Tom and Steve Hemming 2006, 'Conversation: Kunggun Ngarrindjeri Yunnan - Listen to Ngarrindjeri People Talking', in Sharing Spaces: Indigenous and Non-Indigenous Responses to Story, Country and Rights. Gus Worby and Lester-Irabinna Rigney (eds), API Network, Perth: 295-304.

Weatherill, Jay 2013, Eulogy, delivered at the funeral of Tom Trevorrow, 2 May 2013, Meningie. 